The BMJ

kabbasi@bmj.com Follow on Kamran on Twitter @KamranAbbasi Cite this as: BMJ 2021;375:n2735 http://dx.doi.org/10.1136/bmj.n2735 Published: 11 November 2021

\title{
From health to climate there is disrespect at the heart of every crisis
}

\section{Kamran Abbasi executive editor}

Is the prime minister a king? The outrage at Boris Johnson appearing without a mask in so many photos in the media, from sitting beside David Attenborough at the $\mathrm{COP} 26$ climate conference to touring Hexham General Hospital in Northumberland, shows that the court of public opinion will let you get away with only so much (https://www.independent.co.uk/news/health/boris-johnson-mask-nhshospital-backlash-b1954209.html; doi:10.1136/bmj.n2682). ${ }^{12}$

Ironically, healthcare management and leadership are currently high profile areas of government scrutiny, but the premise and objectives behind the scrutiny are misguided, argues Nigel Edwards (doi:10.1136/bmj.n2618). ${ }^{3}$ "The scale, complexity, and political nature of the health service," he explains, "limit the applicability of ideas and interventions from elsewhere." Parachuting in leaders from other industries hasn't worked before in healthcare and won't work now.

Leadership from the top would be a start. The government's own evidence supports masking, and hospitals have clear policies

(https://www.gov.uk/government/publications/facecoverings-and-covid-19-statement-from-an-expertpanel/the-role-of-face-coverings-in-mitigating-thetransmission-of-sars-cov-2-virus-statement-from-therespiratory-evidence-panel). ${ }^{4}$ Yet when the leader of the country considers himself above the rules, as with Johnson's attempts to undermine parliamentary standards on lobbying (doi:10.1136/bmj.n2742) ${ }^{5}$-of direct relevance to the misuse of public funds during the pandemic response-what does that say about our democracy? Clinicians and managers may have little control over events in parliament, but they can control how people behave in their organisations. Why should a prime minister, a citizen, be allowed to break the rules?

Indeed, the concerns of staff seem a low priority for Johnson's government, although its agencies have now quietly but significantly shifted their views on airborne transmission and ventilation

(doi:10.1136/bmj.n2717). ${ }^{6}$ David Oliver describes the ongoing problems in the provision of personal protective equipment (doi:10.1136/bmj.n2704), ${ }^{7}$ and there is a clear sense that staff welfare is not respected.

Respect from political leaders would be a welcome step, says Helen Salisbury (doi:10.1136/bmj.n2716). ${ }^{8}$ What kind of leadership believes that battering staff morale, especially that of part time GPs-many of whom are women-will improve the response to the UK's growing health crisis? Or that a vaccine booster programme can be successfully delivered without those very same staff taking the lead (doi:10.1136/bmj.n2702)? ${ }^{9}$
The absence of a clear health staffing plan was a gaping hole in spending decisions that importantly signalled a shift away from austerity policies but left our editorialists Parth Patel and Lucinda Hiam unconvinced that the fiscal measures announced are enough to reverse a decade's worth of damage to health (doi:10.1136/bmj.n2686). ${ }^{10}$

A clear plan is also needed to reassure staff that healthcare organisations are tackling the evident disrespect and discrimination faced by ethnic minority staff (doi:10.1136/bmj.n2714). ${ }^{11}$ The importance of respect, then, is everywhere. Where is the respect that children deserve as they are left to risk covid for the "greater good"

(doi:10.1136/bmj.n2641)? ${ }^{12}$ Or the respect that patients and colleagues are owed by staff who are opposed to mandatory vaccination (doi:10.1136/bmj.n2670; doi:10.1136/bmj.n2733) $?^{1314}$ Or the respect for people in poor countries as rich countries hoard billions of vaccine doses (doi:10.1136/bmj.n2375) ${ }^{15}$ Respect for our climate might persuade us to abandon travel for international conferences (doi:10.1136/bmj.n2345). ${ }^{16}$

Accepting, albeit belatedly, that health and healthcare are central to the response to the climate crisis, as captured neatly in our infographic (doi:10.1136/bmj.n1284), ${ }^{17}$ is a clear shift. But the response to the climate crisis will be effective only if any motivation to change is coupled with respect for our environment, for people's health, and for the people charged with improving the outcomes for both. This is why, if a prime minister truly respects his citizens and his country, he cannot behave like a king.

Thomas R. Hospital faces backlash after defending Boris Johnson not wearing mask: "inexcusable." Independent. 9 Nov 2021. https://www.inde pendent.co.uk/news/health/boris-johnson-mask-nhs-hospital-backlashb1954209.html.

2 Reicher S, Drury J, Phoenix A, Stokoe LSchool of psychologyneuroscienceSchool of psychologycommunicationmedia. Government ministers and MPs not wearing mask was bad enough, but their defence of this position is even worse. BMJ 2021;375:n2682. doi: 10.1136/bmj.n2682 pmid: 34732391

3 Edwards N. Turning up the heat on the NHS. BMJ2021;375:n2618. doi: 10.1136/bmj.n2618 pmid: 34716144

UK Health Security Agency. The role of face coverings in mitigating the transmission of SARS-CoV-2 virus: statement from the Respiratory Evidence Panel. Oct 2021. https://www.gov.uk/government/publications/face-coverings-and-covid-19-statement-from-an-expert-panel/the-role-of-face-coverings-in-mitigating-the-transmission-of-sars-cov-2-virus-statement-fromthe-respiratory-evidence-panel.

5 O'Dowd A. MPs press for investigation of covid related contracts during "sleaze" debate on standards. BMJ2021;375:n2742.

6 Rimmer A. Sixty seconds on ... hanging around. BMJ2021;375:n2717. doi: 10.1136/bmj.n2717 pmid: 34750152

7 Oliver D. David Oliver: The cultural problems still affecting PPE provision. BM/2021;375:n2704doi: 10.1136/bmi.n2704

8 Salisbury H. Helen Salisbury: What do GPs do all day?BMJ 2021;375:n2716doi: 10.1136/bmi.n2716.

9 lacobucci G. Covid-19: How is the UK's vaccine booster programme faring?BM/2021;375:n2702. doi: 10.1136/bmj.n2702 pmid: 34740926

10 Patel P, Hiam L. What did the spending review do for population health?BMJ 2021;375:n2686. doi: 10.1136/bmi.n2686 pmid: 34750144 
11 Limb M. NHS lacks the fundamental tools required to tackle discrimination, report warns. BMJ 2021;375:n2714. doi: 10.1136/bmj.n2714 pmid: 34750162

12 Alwan NA. We must call out childism in covid-19 policies. BMJ2021;375:n2641. doi: 10.1136/bmj.n2641 pmid: 34716142

13 Sokol D. Covid-19 vaccination should be mandatory for healthcare workers. BM/2021;375:n2670 doi: 10.1136/bmj.n2670 pmid: 34728499

14 Rimmer A. Covid vaccination to be mandatory for NHS staff in England from spring 2022. BMJ 2021;375:n2733doi: 10.1136/bmj.n2733.

15 Feinmann J. Covid-19: global vaccine production is a mess and shortages are down to more than just hoarding. BMJ 2021;375:n2375. doi: 10.1136/bmj.n2375 pmid: 34711605

16 Smith R, Sounderajah V, Darzi A. Have international in-person medical meetings had their day? BMJ 2021;375:n2345doi: 10.1136/bmj.n2345.

17 Rasheed FN, Baddley J, Prabhakaran P, etal. Decarbonising healthcare in low and middle income countries: potential pathways to net zero emissions. BM/2021;375:n1284doi: 10.1136/bmj.n1284. 